Irene Camins

Joseph H. Shinn

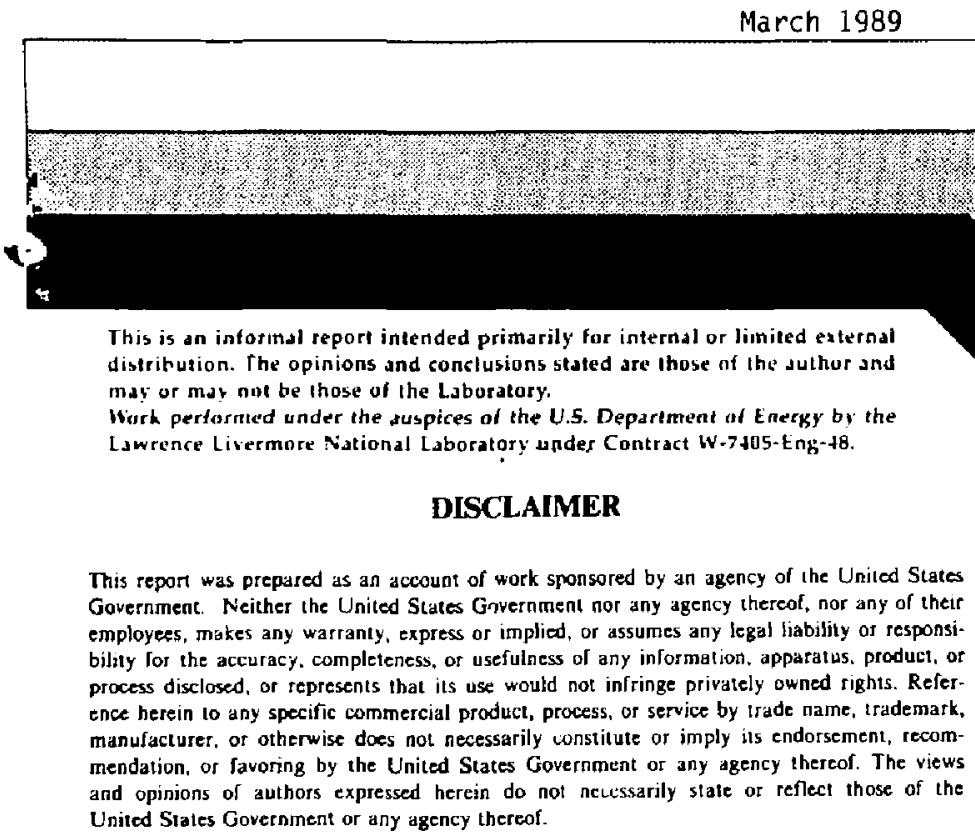




\title{
Analysis of Beryllium and Depleted Uranium: An Overview of Detection Methods in Aerosols and Soils
}

\author{
Irene Camins \\ Joseph H. Shinn
}

June 1988 


\section{Contents}

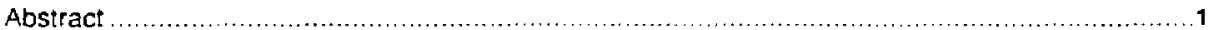

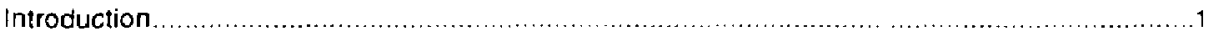

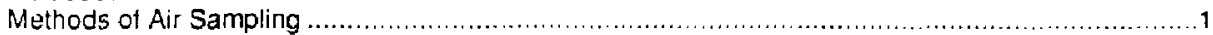

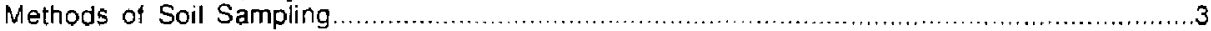

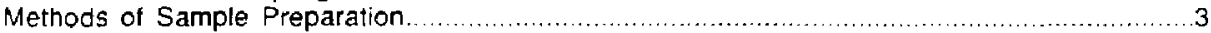

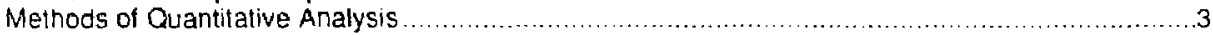

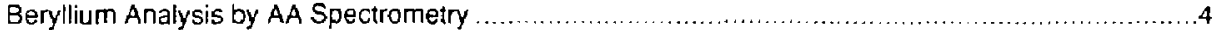

Beryllium Air-Sampling Procedure .. ........................................................4

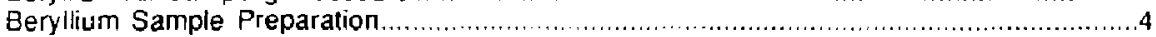

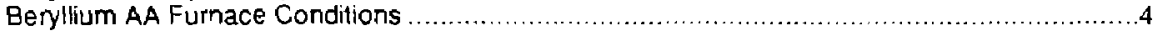

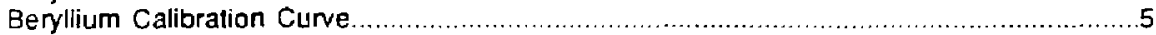

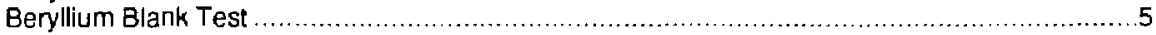

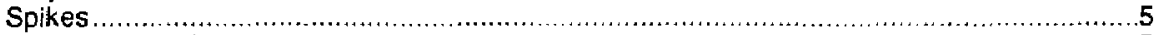

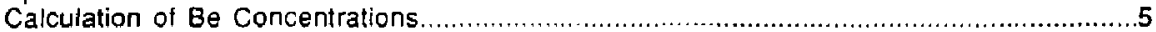

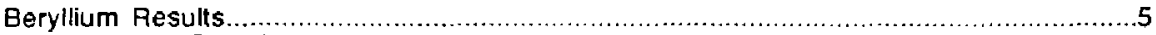

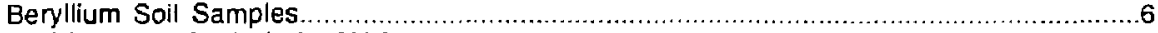

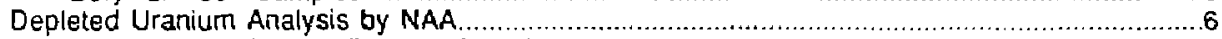

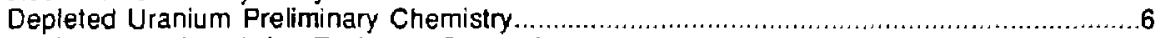

Depleted Uranium Anion-Exchange Separation ..........................................6

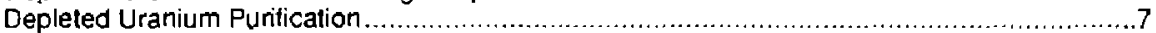

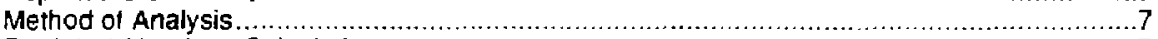

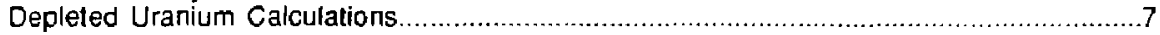

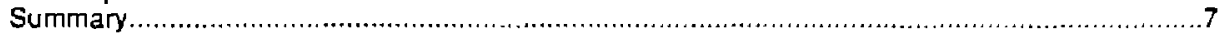

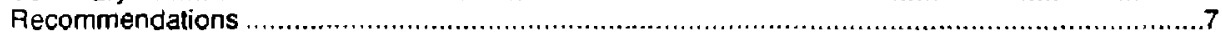

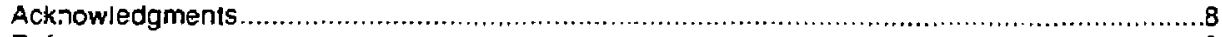

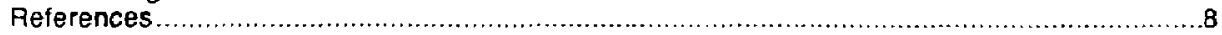

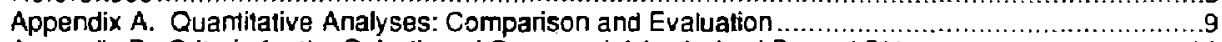

Appendix B. Criteria for the Selection of Commercial Analysis of Be and DU........................20 


\title{
Analysis of Beryllium and Depleted Uranium: An Overview of Detection Methods in Aerosols and Soils
}

\begin{abstract}
We conducted a survey of commercially available methods for analysis of beryllium and depleted uranium in aerosols and soils to find a reliable, cost-effective, and sufficiently precise method for researchers involved in environmental testing at the Yuma Proving Ground, Yuma, Arizona. Criteria used for evaluation include cost, method of analysis, specificity, sensitivity, reproducibility, applicability, and commercial availability. We found that atomic absorption spectrometry with graphite furnace meets these criteria for testing samples for beryllium. We found that this method can also be used to test samples for depleted uranium. However, atomic absorption with graphite furnace is not as sensitive a measurement method for depleted uranium as it is for beryllium, so we recommend that quality control of depleted uranium analysis be maintained by testing 10 of every 1000 samples by neutron activation analysis. We also evaluated 45 companies and institutions that provide analyses of beryllium and depleted uranium.
\end{abstract}

\section{Introduction}

This report on procedures lor detecting beryllium $(\mathrm{Be})$ and depleted uranium $(\mathrm{DU})$ in air and soil samples is intended for the researchers involved in environmental testing at the Yuma Proving Ground, Yuma, Arizona. In this repon, we address inelhods and procedures for the quantitative analysis of $B e$ and DU in air and soil samples. We have chosen these methods based on crileria of cost, method of analysis, specificity, sensitivity, reproducibility, and applicability. In Appendix A, we present our evaluation of 9 methods for quantitative analysis of Be and 10 methods for evaluation of DU. Appendix $B$ contains the results of a survey of $\mathbf{4 5}$ companies and institutions that conduct some of these tests. The companies and institutions were evaluated on the the basis of cost, AlHA certification, method of analysis, turnaround time for 150 samples, sensitivity, and the ability to measure with precision $0.05 \mathrm{mg}$ Be and $0.25 \mathrm{mg}$ DU.

\section{Methods of Air Sampling}

There are four methods of collecting particles of Be and DU from air samples: (1) electrostatic precipitation, (2) dissolution in impinger solutions, (3) collection of settled dust particles in glass jars covered wilh 200 -mesh U.S. standard series screens, and (4) high-volume air fittration. Both the National Institute of Occupational Health (NIOSH) and the Occupational Safety and Health Administration (OSHA) recommend high-volume air filtration (SKC, 1986). "lis advantages include simplicity, low cost, versatility, and the fact that the quantity of collected material usually can be measured without removing it from the paper" (Schulte, 1976). Particles are collected by high-volume air samplers equipped with a cellulosefiber, cellulose-ester, or fiberglass filter. The choice of filter depends on the sample, method of quantitative analysis, sensitivity limits, volume of air drawn, rate of air flow, and sampling duration. Cellulose-ester fitters designated FLT 225-5 are recommended by NIOSH for collecting both Be and DU particles; FLT 225-9 is also recommended for Be particle collection (see Table 1). 
Table 1. Filters recommended by NIOSH (from SKC, 1986).

\begin{tabular}{|c|c|c|c|c|c|c|}
\hline $\begin{array}{l}\text { Filter } \\
\text { type }\end{array}$ & Analyte & $\begin{array}{l}\text { Analysis } \\
\text { method }\end{array}$ & Sensitivity & $\begin{array}{c}\text { Volume } \\
\text { (L) }\end{array}$ & $\begin{array}{c}\text { Rate } \\
(\mathrm{mL} / \mathrm{min})\end{array}$ & $\begin{array}{r}\text { Time } \\
\text { (h) }\end{array}$ \\
\hline \multirow[t]{3}{*}{$\begin{array}{l}\text { FLT } 225.5 \text { mixed } \\
\text { cellulose-ester, } 37 \mathrm{~mm} \\
\text { diameter, } 0.8 \mathrm{~mm} \\
\text { pare size }\end{array}$} & $\mathrm{Be}$ & $\begin{array}{l}\text { Inductively coupled } \\
\text { plasma excitation } \\
\text { atomic emission } \\
\text { spectrometry }\end{array}$ & $0.002 \mathrm{mg} / \mathrm{m}^{3}$ & 1200 & 2500 & 8 \\
\hline & Soluble U & Fluorescence & $2 \mathrm{mg} / \mathrm{m}^{3}$ & 960 & 2000 & 8 \\
\hline & Soluble U & Neutron activation & $0.05 \mathrm{mg} / \mathrm{m}^{3}$ & 960 & 200 & 8 \\
\hline $\begin{array}{l}\text { FLT } 225-9 \text { mixed } \\
\text { cellulose-ester, } 37 \mathrm{~mm} \\
\text { diameter, } 0.45 \mathrm{~mm} \\
\text { pore size }\end{array}$ & $\mathrm{Be}$ & Atomic adsorption & $2 \mathrm{mg} / \mathrm{m}^{3}$ & 90 & 1500 & 1 \\
\hline
\end{tabular}

The sampler for high-volume air filtration includes (1) a high-speed, multistage blower for suction, (2) 8-x-10-in. fitters to trap the particles, and (3) an orifice plate on the back of the blower for monitoring the rate of air flow. Exact measurement of the flow rate can be obtained using a sampler with a self-regulating flow controller to establish a constant flow rate that is independent of particulate loading on the fitter.

Sampling time depends on the needs of each individual study. Most high-volume air samplers operate at a maximum flow of $100 \mathrm{~m}^{3} / \mathrm{h}(60 \mathrm{ctm})$. If the concentration of suspended soil particles is $10 \mu \mathrm{g} / \mathrm{m}^{3}$ (exiremely clean air) and the background levels of $B e$ and DU in the soil are $1 \mu \mathrm{g} / \mathrm{g}$ and $2 \mu \mathrm{g} / \mathrm{g}$. respectively, we would expect the air samplers to collect $1 \times 10^{-3} \mu \mathrm{g} / \mathrm{h}$ of $\mathrm{Be}$ and $2 \times 10^{-3} \mu \mathrm{g} / \mathrm{h}$ of DU. Assuming a detection precision of $0.05 \mathrm{mg}$ for $\mathrm{Be}$ and $0.25 \mathrm{mg}$ for $\mathrm{DU}$, we would operate the air samplers for $50 \mathrm{~h}$ to detect Be and $125 \mathrm{~h}$ to detect DU. Much more time is needed to collect samples to measure significant variations. Because of the trace amounts of suspended Be and DU to be collected and because air samplers can generally operate for two weeks before maintenance is needed, the samplers should be run at least two weeks to produce enough sample material for analysis of background values. Nevertheless, a longer duration may be desirable if the projected amount of sample material collected during this period is insulficient for the instruments used to detect Be and DU.

We recommend a minimum of two weeks of sampler operation even though the resulting sample may be larger than $10 \mu \mathrm{g} / \mathrm{m}^{3}$. We also recommend flow and elapsed-time monitoring during this period. If the detection precision is as assumed above, the samples will have 2.6 times the minimum detectable amount of DU and 6.7 times the minimum detectable amount of Be.

There is, however, at least one disadvantage 10 a two week sampling period. Single events, such as plumes of elevated Be and DU from explosives lests or from resuspension by a gust of wind blowing over contaminated sites, will have very little effect on a value determined over two weeks. In such cases, some other method should be considered for detecting single-event concentrations. 


\section{Methods of Soil Sampling}

Soil sampling requires a strategy tor obtaining representative samples of deposited Be aric DU This strategy is straighttorward: it consists of randomLy taking shallow scoops of surface soll and pooling them. If details about horizontal deposition patterns are required, then the scooping and pooling should be done over a small area (on the order of $1 \mathrm{~m}^{2}$ ), but otherwise a larger area should be randomly sampled. After drying, sieving, and mixing the sample, a small aliquot can be removed for analysis. Please rote, however, that because background concentrations of Be and DU can be quite variable, it may be difficult to detect the slight changes in the surface soil caused by a particular event.

\section{Methods of Sample Preparation}

Many of the quantitative analytical methods for detection of Be and DU require pretreatment of the sample, which includes grinding, fusion, and ashing. Large samples of soil may have to be ground small enough to pass through a 200 -mesh sieve. The sample must then be agitated in a mixer mill, and either fused or ashed before it can be quantitatively analyzed.

Fusion is an efficient method ter removing refractory contaminants, such as silicates and fluorides. from samples. The decomposition of refractory ores is essential to ensure quantitative results by a spectrographic method. Two common fusion methods are carbonate/tetraborate fusion and potassium fluoride/sodium pyrosulfate fusion. Carbonate/tetraborate fusion yields a complete analysis of the sample including silica. Dehydration and separation of silica should follow. Potassium fluoride/sodium pyrosulfate fusion is excelient for the cecomposition of refractory silicates with the elimination of silica and fluorides.

Ashing destroys all organic matter in the sample before ore separation. There are two types of ashing: dry and wet. Dry ashing is recommended only for large soil samples or bone samples. This method must be followed by a concentration procedure to reduce the sample volume and suspend the sample in solution for further analysis. Wet ashing is favored over ary ashing because it reduces the risk of exchanging Be and DU to or from the glaze of containers and it is more adaptable to the simultaneous processing of large numbers of samples. Moreover, because the wet ashing procedure suspends the sample in solution, standardized calibration curves of known concentrations, which are difficult to prepare when analyzing solids, are easily creatid.

Nitric acid and perchtoric acid are two examples of wet ashing reagents. Other strong acids, such as hydrofluoric acid, can be used as well. Nitric acid wet ashing has been proven to provide quantitative recoveries of known activities of ${ }^{7}$ Be tracer (U.S. Public Health Service. 1966). After nilric acid wet ashing, potassium fluoride/sodium pyrosulfate fusion may be needed to convert all the Be to soluble form; if all Be is already in soluble form, nitric acid wet ashing alone is sufficient before quantitalive analysis by spectrographic or chemical methods. Perchloric acid wet ashing is an excellent alternative method to fusion when eliminating refractory oxides in ore samples. The use of perchloric acid, however, requires special safety measures; the perchloric wet ashing method must be contained in specially fabricated perchloric acid fume hoods for proper ventilation.

Wet ashing provides many benefits for sample preparation above those provided by dry ashing; thus, we recommend it before any instumental analysis of Be or DU.

\section{Methods of Quantitative Analysis}

After the sample is pretreated, it is ready for quantitative analysis. There are a variety of methods, chemical treatments, and instruments used for the detection of $B e$ and DU. Atomic absorption (AA) spectrometry, emission spectroscopy with an inductively coupled plasma excitation source (ICP), $x$-ray fluorimetry (XAF), and neutron activation analysis (NAA) are the most commonly used analytical methods in industry (see Appendix B). These methods can be automaled; they are highly specific and extremely sensitive and, thus, yield results that can be more accurately reproduced than those from traditional wetchemistry methods. We recommend AA spectrometry with graphite furnace for the highly sensitive 
analysis of Be air perticles and as a quality control method for Be sample testing. We recommend NAA for 10 of every 1000 DU samples as a quality control measure and AA spectrometry with graphite fumace or XRF for the routine analysis of DU samples.

\section{Beryllium Analysis by AA Spectrometry}

An exact method of Be analysis from sampling to AA determination has been described by Zdrojewski et al. (1976). This group has quantitatively compared the flame and flameless (graphic furnace) modes of $A A$ for Be detection. They found the Be sensitivity to be better with a graphite furnace than with the flame detector. We cite their method as an example of a total analysis procedure for Be.

The following is a general description of their procedure: (1) an air sample was drawn; (2) a sample was cut trom the tilter paper; (3) the sample was digested: (4) the digested volume was adjusted; and (5) the sample was either aspirated into the flame or furnace of the spectrometer. Each step of the procedure is described below.

\section{Beryllium Air-Sampling Procedure}

Zdrojewski and associates used cellulose, ashless, acid-washed, analytical-grade filters, 203 by $254 \mathrm{~mm}$, without any pretreatment. For these filters, a sample volume of $1000 \mathrm{~m}^{3}$ or less was used. Glassfiber filters were also used, but were pretreated with copious amounts of distilled water. (Membrane filters are not recommended for use because of the nonuniformity of the exposed surface area and the resulting nonuniformity of particle collection.) The filters were mounted in a high-volume sampler with a flow rate between $66 \mathrm{~m}^{3} / \mathrm{h}$ and $100 \mathrm{~m}^{3} / \mathrm{h}$ for a 24-h duration. The total volume of air sampled was the result of the mean flow rate and elapsed time.

\section{Beryllium Sample Preparation}

Areal aliquots (discs) were cut from the filters with a metal punch, which was a sharp, circular, stainless steel die. The punch was wiped with tissue between samples to prevent sample contamination. This method provided an accurate replication of sample portions with litlle contamination. The amount of liter taken lor analysis was, by design, $5 \%$ of the exposed 8-x-10-in. filter. One or more of the discs were placed in a Teflon beaker; then, $1 \mathrm{~mL} 49 \%$ hydrofluoric acid was added dropwise to start dissolution. The solution was warmed gently until almost all the hydrofluoric acid had evaporated. Next, 1 to $2 \mathrm{~mL} 71 \%$ nitric acid was added, and the solution was heated until only a few drops were left. At this point, $10 \mathrm{~mL}$ distilled water was added. and the solution was brought almost to boiling. The solution was then filtered through a Whatman-41 filter into a glass beaker and later transferred to a $25-\mathrm{mL}$ volumetric llask. The Teflon beaker was rinsed with another $10 \mathrm{~mL}$ distilled waler and warmed. This aliquot was also transferred into the $25-\mathrm{mL}$ volumetric flask, and the flask was filled to $25 \mathrm{~mL}$ with distilled water at $25^{\circ} \mathrm{C}$. This final volume was mixed thoroughly and run on the AA spectrometer.

\section{Beryllium AA Furnace Conditions}

The furnace operating conditions for $\mathrm{B}_{\theta}$ detection were the following: (1) the monochrometer wavelength was set at $234.8 \mathrm{~nm}$; (2) the purging gas was argon or nitrogen; (3) a sample size of $20 \mathrm{~mL}$ was used, and (4) a deuterium-amp background compensator was recommended. Under these conditions, $20 \mathrm{~s}$ at $100^{\circ} \mathrm{C}$ caused thermal decomposition, $20 \mathrm{~s}$ at $1100^{\circ} \mathrm{C}$ caused charting, and $20 \mathrm{~s}$ at $2400^{\circ} \mathrm{C}$ caused atomization. Experiments indicated that the maximum response for Be was an atomization voltage between 9 and 10 . The total amount of $\mathrm{Be}$ in the sample was determined by comparison to a standardized calibration curve. 


\section{Beryllium Calibration Curve}

The range of the calibration curve was 0.2 to $1.0 \mathrm{ng}$ of $\mathrm{Be}$ in steps of $0.2 \mathrm{ng}(0.01$ to $0.05 \mu \mathrm{g} / \mathrm{mL}$ for a 20-mL sample). A plot was drawn with the standardized Be concentration in $\mu \mathrm{g} / \mathrm{mL}$ on the horizontal axis and the response in arbitrary units on the vertical axis.

\section{Beryllium Blank Test}

Blanks of all the acids used were run with the procedural dilutions and extractions; those of distilled water were also run to establish any background contamination. (Blanks with unusually high readings would require purification or change of reagents.) Unexposed filters were digested and run on the spectrometer to standardize the background level of $\mathrm{Be}$ and to determine sources of contamination,if any.

\section{Spikes}

As an added quality control measure, we also recommend National Bureau of Standards (NBS) standardized samples of preweighed Be to be placed on unexposed filters and carried through the entire analysis trom digestion to instrumentation.

\section{Calculations of Be Concentrations}

For the determination of the unknown Be concentration "X" ( $\mu \mathrm{g} / \mathrm{mL})$ in a sample, Zdrojewski et al., subtracted the blank concentration $X_{2}(\mu g / L)$ from the measured value $X_{1}$, and the result was multiplied by the dilution factor of 25 :

$$
x=25\left(x_{1}-x_{2}\right) \text {. }
$$

For determining Be in air from high-volume filters sized $203 \mathrm{~mm}$ by $254 \mathrm{~mm}$, the following formula was used:

$$
T=\frac{\left(x_{1}-x_{2}\right) \times 20.43 \times 25}{V} .
$$

where $\quad \begin{array}{lll}T & = & \text { total Be concentration in } u g / \mathrm{m}^{3} \text { air, } \\ V & = & \text { volume of air sampled in } \mathrm{m}^{3} \\ X_{1} & = & \text { response.unknown test portion, } \\ X_{2} & = & \text { response, total blank, } \\ 25 & = & \text { dilution factor in } \mathrm{mL}, \\ 20.43 & = & \text { surtace multiplication faclor for the total exposed filter surface of } 4.159 \times \\ & & 10^{4} \mathrm{~mm}^{2} \text { and an areal sample of } 2 \times 36 \mathrm{~mm} \text { discs, or } 2036 \mathrm{~mm}^{2} .\end{array}$

\section{Beryllium Results}

Zdrojewski et al. (1976) found their method for AA with a graphite furnace sutficiently sensitive to measure $0.00005 \mu \mathrm{g} / \mathrm{m}^{3}$. They found the tilter blank to be about $0.001 \mu \mathrm{g} / \mathrm{mL}$ to $0.0009 \mu \mathrm{g} / \mathrm{mL}$ because of interterence from elements such as $\mathrm{Na}, \mathrm{Ba}, \mathrm{Si}, \mathrm{Ca}, \mathrm{Zn}, \mathrm{K}$, and $\mathrm{Al}$ in the filter. In addition, they observed a relative uniformity between fitters of $\pm 10 \%$. Furthermore, their instrumental precision maintained a standard deviation of $0.040 \pm 0.0011 \mu \mathrm{g} / \mathrm{mL}$ for 10 repeated measurements of Be standards. The minimum amount of Be they were able to measure was $0.0002 \mu \mathrm{g} / \mathrm{mL}$ in solution and $0.00005 \mu \mathrm{g} / \mathrm{m}^{3}$ in air. 


\section{Beryllium Soil Samples}

Soil samples of Be should be analyzed in a manner similar to air samples, although large aliquots would have to be dissolved to measure low Be concentrations, which would be difficult and very lime consuming.

\section{Depleted Uranium Analysis by Neutron Activation Analysis}

For precise, accurate measurements of DU on airborne particles, we recommend NAA, which is commercially available. It should be noted that NAA requires no sample preparation; the filter papers can be analyzed directly. The limitations of this method are that it is costly and that results may be delayed up to six weeks to allow for radioactive decay of the sample. For this reason, we recommend routine analysis by ICP or XRF, with quality control of 10 out of every 1000 samples on NAA. Another suitable technique is AA spectrometry with a graphite furnace, atthough this technique is not as sensitive to DU as it is to Be.

For the analysis of DU on AA with a graphite furnace, ICP, or XRF, a procedure for sample preparation similar to the one just described for $B \theta$ should be used. but the operating conditions, as well as the preliminary chemistry for the air filters, will be slightly differemt to ensure DU specificity.

As an example of a preparation method developed for the analysis of $\mathrm{DU}$, we cile procedures carnied out here at Lawrence Livermore National Laboratory. The DU air filters are analyzed in three parts using a preliminary chemistry technique, an anion-exchange separation method, and a uraniumpurification step (Garrison, 1988). The preliminary chemistry, anion exchange, and puritication are described in more detail below. Again, note that should NAA be used, no sample preparation is necessary because the filters can be analyzed directly.

\section{Depleted Uranium Preliminary Chemistry}

The preliminary chemistry for DU begins with tracing the air-sampler filters and ashing them in a furnace at $475^{\circ} \mathrm{C}$ for at least two days. Ashed samples not already in platinum beakers should be transferred to such beakers using a minimum amount of concentrated nitric acid. After transfer of the sample, more nitric acid is added to give a total volume of $30 \mathrm{~mL}$. Next, $30 \mathrm{~mL}$ of hydrofluoric acid is added. The sample is heated to dryness in an acid fume scrubber; then, $30-\mathrm{mL}$ aliquots of both concentrated nitric acid and perchloric acid are added. The solution is heated in the scrubber until the fuming ceases. As much of the residue as possible is dissolved by heating the residue again with $20 \mathrm{~mL}$ $8 \mathrm{M}$ nitric acid and a few drops of $30 \%$ hydrogen peroxide. Next, a minimal amount of $8 \mathrm{M}$ nitric acid is used to transfer the solution to a $250-\mathrm{mL}$ plastic bottle. Finally, all samples are treated with $0.5 \mathrm{~g}$ of sodium nitrite $\left(\mathrm{NaNO}_{2}\right)$ to adjust the uranium valence to +4 for anion exchange, and the samples are set aside for at least four hours belore further processing.

\section{Depleted Uranium Anion-Exchange Separation}

For the anion-exchange separation step, a large column is loaded with preconditioned $1 \times 8,5010$ 100 mesh ( $\mathrm{Cl}^{-}$form) anion-exchange resin to a height of about $24 \mathrm{~cm}$, followed by $1 \mathrm{~cm}$ of preconditioned $A G 1-X B, 100$ to 200 mesh ( $\mathrm{Cl}^{-}$lorm) anion-exchange resin. After the column is conditioned with $50 \mathrm{~mL}$ $8 \mathrm{M}$ nitric acid. the sample is filtered through a $934 \mathrm{AH}$ glass-fiber filter paper onto the column. When the liquid is has run through the column, the tilter paper is rinsed well with $8 \mathrm{M}$ nitric acid, and the the column reservoir is rinsed twice with $8 \mathrm{M}$ nitric acid. Then, the resin is washed with $50 \mathrm{~mL}$ of $8 \mathrm{M}$ nitric acid. At this point, the column is rinsed with concentrated hydrochloric acid and the resin washed with $100 \mathrm{~mL}$ hydrochloric acid. The DU is eluted with $80 \mathrm{~mL} 0.1 \mathrm{M} \mathrm{HCl}$ into a $150-\mathrm{mL}$ beaker and evaporated to dryness. Depleted uranium purification is the next step. 


\section{Depleted Uranium Purification}

The first action in purifying the $\mathrm{DU}$ is to dissolve the sample in 1 to $2 \mathrm{~mL}$ concentrated $\mathrm{HNO}_{3}$ with heat and transier it with water to a $50-\mathrm{mL}$ glass centrituge tube. Next, $1 \mathrm{~mL}(5 \mathrm{mg} / \mathrm{mL})$ lanthanum carrier is added to all DU samples (except those derived from soil chemistry). The sample is made alkaline with concentrated $\mathrm{NH}_{4} \mathrm{OH}$. After the sample is heated in an $80^{\circ} \mathrm{C}$ water bath for at least $5 \mathrm{~min}$, it is centrifuged and the supernatent is discarded. The precipitate is dissolved with a minimum amount of $1 \mathrm{M}$ suffuric acid and heated in a water bath 10 facilitate the dissolution. The solution is then diluted to $5 \mathrm{~mL}$ with distilled water. All steps after the addition of the lanthanum carrier are repeated twice. After the precipitate is dissolved and diluted to $5 \mathrm{~mL}$ a third time, it is diluted to $15 \mathrm{~mL}$ with $0.06 \mathrm{M}$ sulfuric acid. Then, a small ionexchange column is loaded to a height of 2 to $3 \mathrm{~cm}$ with preconditioned AG1-X8, 30 to $70 \mathrm{~mm} / \mathrm{min}$ uranium anion-exchange resin (sulfate ion). This column is conditioned with $10 \mathrm{~mL} 0.06 \mathrm{M} \mathrm{H}_{2} \mathrm{SO}_{4}$ and the sample is loaded onto it. After the liquid is run through the column, the column reservoir is rinsed four times with $5 \mathrm{~mL} 0.06 \mathrm{M} \mathrm{H}_{2} \mathrm{SO}_{4}$ i the reservoir is allowed to drain completely between rinses. Next, the resin is washed with $5 \mathrm{~mL}$ concentrated $\mathrm{HCl}$, followed by a wash with $5 \mathrm{~mL} 6 \mathrm{M} \mathrm{HCl}$, and the DU is eluted into vials with $10 \mathrm{~mL} 0.1 \mathrm{M} \mathrm{HCl}$. Finally, each vial is labelled, and the contents of the vials are evaporated to dryness under a heat lamp. Samples frequently need to be dissolved in aqua regia and evaporated to dryness again before instrumental analysis.

\section{Method of Analysis}

Lawrence Livermore National Laboratory uses emission spectroscopy with inductively coupled plasma/mass spectrometry (ICP/MS) for the detection of DU air particles in solution, but AA with graphite fumace, XRF, or ICP are commercially available and can also be used after this method of preparation.

\section{Depleted Uranium Calculations}

The calculations for determining DU concentration should be carried out in the same manner as those set out for $B e$ concentrations, based on the creation of a calibration curve. Blanks and spikes must be used for quality control.

\section{Summary}

Zdrojewski et al. (1976) have described an exact method for analyzing $\mathrm{Be}$. By companing modes of AA spectrometry for Be determination, they determirıed that the graphite furnace was more sensitive to Be than the flame detector. They found their filter blank to be about $0.001 \mu \mathrm{g} / \mathrm{mL} 100.0009 \mu \mathrm{g} / \mathrm{mL}$ because of interlerence from elements such as $\mathrm{Na}, \mathrm{Ba}, \mathrm{Si}, \mathrm{Ca}, \mathrm{Zn}, \mathrm{K}$, and $\mathrm{Al}$. They also found a relative uniformity between fitters of $\pm 10 \%$. After reviewing their method, we conclude that it is the most accurate commercially available procedure for the determination of $\mathrm{Be}$. (The soil analysis of Be following the same procedures that were described on the previous pages would require large aliquots of soil, which would be difficult to dissolve and time consuming to analyze.)

At the Lawrence Livermore National Laboratory, DU air filters are prepared for analysis using a preliminary chemistry lechnique, an anion-exchange separation method, and a urarium purification step. The method of instrumental analysis is ICP/MS, but other instruments such as AA with graphite furnace. $X R F$, or ICP can be used. However, AA with graphite fumace is not as sensitive to the measurement of DU as it is of $\mathrm{Be}$. Neutron activation analysis, on the other hand, is more sensitive than AA to DU: but the limitations of NAA are that it is both costly and time consuming (results may be delayed up to six weeks to allow for radioactive decay of the sample) and, therefore, it is only recommended as a quality control measure. 


\section{Recommendations}

We make the following recommendations for measuring and analyzing $\mathrm{Be}$ and $\mathrm{DU}$ :

- High-volume air sampiers with cellulose-ester fiber filters should be used for obtaining samples.

- Atomic absorption with graphite fumace snould be used for analyzing Be air particles and soil samples.

- We strongly recominend that depleted uranium samples be analyzed by NAA for quality control on 10 of every 1000 samples analyzed

- Routine analysis of DU can be performed using AA with graphite furnace, ICF', or XRF.

- Standards should be run for calibration curves to establish the concentratio's of both Be and DU.

- Blanks and spikes should be analyzed to establisı Dackground levels and to ensure instrumental precision.

- If the readings lor blanks of acid or blanks of the distilled water with procedural dilution are high, puritication is necessary. Unexposed filters should then be digested and run on AA to standardized the background levels of Be, and prevent unnecessary sources of contamination.

- The calculations of Be and DU should be similar to the calculations presented in this report.

- Other methods of instrumental analysis tinan AA with graphite fumace for Be and NAA for DU should be used if great sensitivity is not needed and background monitoring demonstrates high levels of Be and DU.

\section{Acknowledgments}

I thank Mike Angel and Tom Kulp for the opportunity to write this report.

\section{References}

Garrison, J., Nuclear Chemisiry Deparment, Lawrence Livermore National Laboratory, Livermore, CA, private communication (1988).

Schulte, H. G., "Radionuclide Surveillance," in Air Pollution: Yolume lll: Measuring. Monitoring and Surveillance or Air Pollution, A. C. Stern, Ed. (Academic Press, New York, NY, 1976), Pp. 413-451.

SKC, Guide lo NIOSH/OSHA Air Sampling Standards. (1986).

U.S. Public Health Service, Beryllium: Its IndustrialHyoiene Aspects, U.S. Public Health Service, Division of Occupational Health, Toxicology Section (Academic Press, New York, NY, 1966).

Zdrojewski, A., L. Dubois, and N. Quickent, "Rejerence Method for the Determination of Beryllium in Airborne Particulates, "Sci_Iotal Enyiron. 6. 165-173 (1976). 


\section{Appendix A. Quantitative Analyses: Comparison and Evaluation}

Several analytical methods used to detect Be and DU were reviewed. and evaluated based on the following criteria:

1. Speciticity.

2. Sensitivity.

3. Reproducibility.

4. Applicability.

Sources for the information about the methods and an overall evaluation are given in a tabular form on the following pages. (Because most analytical instnuments used for the determination of the amount of Be and DU require samples that are in solution, we used the conversion, factor $1 \mu \mathrm{g} / \mathrm{mL}=$ $1 \times 10^{6} \mu \mathrm{g} / \mathrm{m}^{3}$ to convert air concentrations to concentrations in solution in $\mu \mathrm{g} / \mathrm{mL}$.)

\section{Sources of Methods Reviewed}

Amiel, S., " Analytical Applications of Delayed Neutron Emission in Fissionable Elements," Anal. Chem. 34, 1683-1692 (9962).

Cheremisinof, P. N.. Air Pollution Sampling Analysis Deskbook (Ann Arbor Science, Ann Arbor, MI, 1978).

Dionex, "Dionex Technical Note 10R," Dionex 2000i lon Chromatography Manual, Dionex,

Sunnyvale, $\mathrm{CA}$.

Dulka, K. K., and T. H. Risby, "Ultratrace Metals in Some Environmental Biolggical Systems, "Anal. Chem 48. 640A-653A (1976).

Maccioli, F. K., and T. H. Risby, Determination of Toxic Metals and Metalloids in Ambient Air (The Pennsylvania State University Press, University Park, PA, 1978).

Mallessa, H., Analysis of Airbome Particles by Physical Methods (CRC Press, Palm Beach, FL, 1978).

Myers, W. G. and J. A. White, "Mass Spectrometry and Fission Track Analysis in Nuclear Environmental Measurements," in Eroceedings of American Nuclear Societv Topical Meetine on Nuclear Methods in Environmental Research, August 23-24 (1971).

Pankartz, D., Aerovironment, Monrovia, CA, private communication (1988).

Russ, P. Nuclear Chemistry Department, Lawrence Livermore National Laboratory, Livermore, CA, private communication.

Sill., C. W., "Determination of Thorium and Uranium Isotopes om Ores and Mill Tailings by Aipha Spectrometry," Anal Chem. 49, 618-621 (1977).

U.S. Public Health Service, Bexdlium: It Industrial Hygiene Aspects, U.S. Public Health Service, Division of Occupational Health, Toxicology Section (Academic Press, New York, NY, 1966).

Zitlel, H. E., and L. B. Dunlap, "Polarographic Determination of Uranium (IV) in Sodium Tripolyphosphate Supporting Electrolyte," Anal. Chem. 34, 1757-1760 (1962). 


\section{Quantitative Analysis of Beryllium}

Table A-1. Evaluation of colorimetry as a method for the quantitative analysis of beryllium (U.S. Public Health Service, 1966).

\begin{tabular}{|c|c|c|c|}
\hline Specilicity & Sensitivity $(\mu \mathrm{g} / \mathrm{mL})$ & Reproducibility & Applicability \\
\hline $\begin{array}{l}\text { Method alone is } \\
\text { nonspecific. Method } \\
\text { must be used in } \\
\text { conjunction with other } \\
\text { methods to eliminate } \\
\text { interference } \\
\text { compounds. }\end{array}$ & 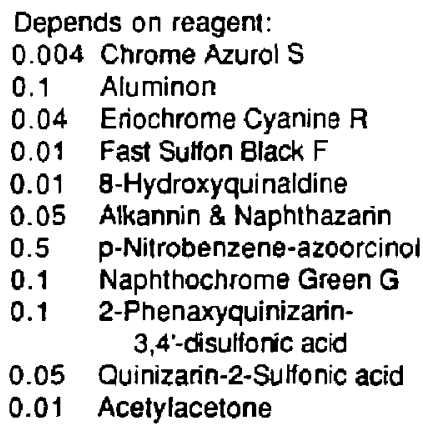 & $\begin{array}{l}\text { Precision is dependent } \\
\text { upon the performance of } \\
\text { the wet chemistry } \\
\text { technique, not the actual } \\
\text { analytical method. }\end{array}$ & Universal \\
\hline
\end{tabular}

\section{Overall Evaluation}

The colorimetric method is subjective and therefore results are difficult to reproduce. This method is recommended as an inexpensive qualitative analysis method for Be. 
Table A-2. Evaluation of atomic absorption as a method for the quantitative analysis of beryllium (Maccioll and Risby, 1978).

\begin{tabular}{|c|c|c|c|}
\hline Specificity & Sensitivity & Reproducibility & Applicability \\
\hline $\begin{array}{l}\text { Method is highly } \\
\text { specific. }\end{array}$ & $\begin{array}{l}0.003 \mu \mathrm{g} / \mathrm{m}^{3} \text { flame } \\
\left(3 \times 10^{-9} \mu \mathrm{g} / \mathrm{mL}\right) \\
0.007 \mathrm{ng} / \mathrm{m}^{3} \mathrm{graphite} \text { furnace } \\
\left(7 \times 10^{-12} \mu \mathrm{g} / \mathrm{mL}\right)\end{array}$ & $\begin{array}{l}\text { Coefficient of variation is } \\
\text { about } 0.5 \text { io } 2 \% \text {. Precision } \\
\text { is dependent upon the } \\
\text { pertormance of the wet } \\
\text { chemistry technique, not the } \\
\text { actual analytical method. }\end{array}$ & Universa, \\
\hline
\end{tabular}

\section{Overall Evaluation}

Atomic absorption spectrometry with flame detector is a very good method to use for the detection of $\mathrm{Be}$. The flame detector is as accurate as the graphite furnace apparatus, but is not as highly sensitive.

Atomic absorption spectrometry with a graphite furnace is an excellent method for the detection of $\mathrm{Be}$. The operation can be fully automated; it is extremely sensitive; Be spectra are highly specific; an operator can easily be trained to maintain the instrument; the analysis is not extremely labor intensive; and there are few interferences.

Table A-3. Evaluation of emission spectroscopy with high-energy excitation source, such as flame. AC arc, DC arc, and AC spark, as a method for the quantitative analysis of beryllium (U.S. Publlc Health Service, 1966).

\begin{tabular}{llll}
\hline Specificity & Sensitivity & Reproducibility & Applicability \\
\hline $\begin{array}{l}\text { Method is highly } \\
\text { specific provided an. }\end{array}$ & $0.005 \mu \mathrm{g} / \mathrm{m}^{3}$ & $\begin{array}{l}\text { Precision is dependent } \\
\text { upon the pertormance of the } \\
\text { instrument of sutficient }\end{array}$ & $\begin{array}{l}\text { wet chemistry technique, not } \\
\text { the actual analytical method. }\end{array}$
\end{tabular}

\section{Overall Evaluation}

Emission spectroscopy with high-energy excitation source can be automated; however, the radiation intensities can be difficult to reproduce from one analysis to another and the error ranges from \pm 10 to $\pm 20 \%$. The method can be optimized with due care to reproducibility and have an error range of only \pm 1 to $2 \%$. 
Table A-4. Evaluation of emission spectroscopy with inductively coupled plasma excitation source (ICP or ICAP) as a method for the quantitative analysis of beryllium (Mallessa, 1978).

\begin{tabular}{|c|c|c|c|}
\hline Specificity & Sensitivity & Reproducibility & Applicability \\
\hline $\begin{array}{l}\text { Method can give } \\
\text { simultaneous information } \\
\text { on several elements at one } \\
\text { time. However, the plasma } \\
\text { zone is highly specitic tor } \\
\text { each element. }\end{array}$ & $0.0005 \mu \mathrm{g} / \mathrm{mL}$ & $\begin{array}{l}\text { Reproducibility is excellent, the } \\
\text { method can be fully automated. } \\
\text { Aithough solid samples can be } \\
\text { measured directly, standardization } \\
\text { is difficulf for solids; therefore, samples } \\
\text { should be in solution. Precision is } \\
\text { dependent upon the performanze of } \\
\text { the wet chemistry technique, not the } \\
\text { actual znalytical method. }\end{array}$ & Universal \\
\hline
\end{tabular}

\section{Overall Evaluation}

The ICP method requires the addition of internal standards, which would be more labor intensive than other methods. This method can be readily automated; it is highly sensitive; it can analyze more than one element at a time, and is, therefore, excellent for multiple analyses.

Table A-5. Evaluation of fluorimetry as a method for the quantitative analysis of beryllium (U.S. Public Health Service, 1966).

\begin{tabular}{|c|c|c|c|}
\hline Specificity & Sensitivity $(\mu \mathrm{g} / \mathrm{mL})$ & Reproducibility & Applicability \\
\hline $\begin{array}{l}\text { Method alone is } \\
\text { nonspecific. Method } \\
\text { must be used in } \\
\text { conjunction with other } \\
\text { methods to eliminate } \\
\text { interterence } \\
\text { compounds. }\end{array}$ & $\begin{array}{l}\text { Depends on reagent: } \\
0.0002 \text { Morin } \\
0.025 \text { 1,4-Dihydroxyanthraquinone } \\
0.006 \text { 3,8-Hydroxyquinaldine }\end{array}$ & $\begin{array}{l}\text { Precision is dependent } \\
\text { upon the pertormance of } \\
\text { the wet chemistry } \\
\text { technique, not the actual } \\
\text { analytical method. }\end{array}$ & Universal \\
\hline
\end{tabular}

\section{Overall Evaluation}

There are several compounds that may interfere with Be fluorescence and must be eliminated; this can be a very labor-intensive procedure. 
Table A-6. Evaluation of gas-liquid chromatography with electron capture detector as a method for the quantitative analysis of beryllium (Maccioli and Risby, 1978).

Specificity

Method alone is nonspecific. Method must be used in conjunction with other methods to eliminate interference compounds. Sensitivity

$4 \times 10^{-14} \mathrm{~g}$

$\left(4 \times 10^{-7}(\mu \mathrm{g} / \mathrm{mL})\right.$
Reproducibility

Precision is dependent upon the pertormance of the wet chemistry technique, not the actual analytical method. Applicability

\section{Overall Evaluation}

An excellent method. It is highly sensitive, extremely accurate and can be easily automated. There are interferences that must be chemically eliminated.

Table A-7. Evaluation of gravimetric precipitation as a method for the quantitative analysis of beryillum (U.S. Public Health Service, 1966).

Specificity

Method alone is nonspecific. Method must be used in conjunction with other methods to eliminate interference compounds.
Sensitivity

$1105(\mu \mathrm{g} / \mathrm{mL})$
Reproducibility

Precision is dependent upon the periormance of the wet chemistry technique, not the actual analytical method.
Universal

\footnotetext{
compounds.
}

\section{Overall Evaluation}

The results are often difficult to reproduce when using gravimetric methods and working with trace quantities. Losses occur due to occlusion, adsorption, and coprecipitation. This method is not recommended by itself; it must be coupled with other methods and carefully tested before any routine use. 
Table A-8. Evaluation of lon chromatography (IC) as a method for the quantitative analysis of beryllium (Dionex, 1983).

\begin{tabular}{|c|c|c|c|}
\hline Specificity & Sensitivity & Reproducibility & Applicability \\
\hline $\begin{array}{l}\text { Method is highly } \\
\text { specific. However, } \\
\text { it must be combined } \\
\text { with a postcolumn } \\
\text { derivatization and } \\
\text { subsequent flow through } \\
\text { absorbance detector. }\end{array}$ & $\begin{array}{l}\text { Mid to low parts per billion } \\
\text { (ng/mL). Excellent for trace } \\
\text { analyses. } \\
\left(1 \times 10^{-3} \mu \mathrm{g} / \mathrm{mL}\right)\end{array}$ & $\begin{array}{l}\text { Samples must be } \\
\text { completely in solution } \\
\text { and free of particulates; } \\
\text { therefore,precision is } \\
\text { dependent upon the } \\
\text { performance of the } \\
\text { chemistry technique, not } \\
\text { the actual analytical method. }\end{array}$ & $\begin{array}{l}\text { Excellent } \\
\text { for micro- } \\
\text { samples }\end{array}$ \\
\hline
\end{tabular}

\section{Overall Evaluation}

There are interferences that must be chemically eliminated. Also, some problems exist with the oxidation of $\mathrm{Be}$; this might be eliminated if $\mathrm{IC}$ is combined with colorimetry.

Table A-9. Evaluation of x-ray fluorescente as a method for the quantitative analysis of beryllium (Maccioll and Risby, 1978).

\begin{tabular}{|c|c|c|c|}
\hline Speciticity & Sensitivity & Reproducibility & Applicability \\
\hline $\begin{array}{l}\text { Spectra of each } \\
\text { elements is highly } \\
\text { specific; however, } \\
\text { interfering elements } \\
\text { can change } \\
\text { fluorescent intensity. }\end{array}$ & $\begin{array}{l}7.5 \mu \mathrm{g} / \mathrm{g} \\
\text { (assuming } 10 \mathrm{mg} / \mathrm{m}^{3} \text { air, } \\
\text { then concentration equals } \\
75 \mu \mathrm{g} / \mathrm{mL} \text { ) }\end{array}$ & $\begin{array}{l}\text { Can eliminate problems } \\
\text { associated with interfering } \\
\text { compounds by using a } \\
\text { monochromatic source for } \\
\text { selective excitation. A very } \\
\text { time-consuming process. }\end{array}$ & Solid state \\
\hline
\end{tabular}

\section{Overall Evaluation}

The analysis of $B e$ samples using $x$-ray fluorescence can be labor intensive, due to the necessary elimination of interference compounds to the Be spectra. A monochromatic source would definitely be needed to reduce the interterences and automate the system. 


\section{Quantitative Analysis of Depleted Uranium}

Table A-10. Evaluation of atomic absorption as a method for the quantitative analysis of depleted uranium (Cheremisinot, 1978).

\begin{tabular}{llll} 
Specificity & Sensitivity & Reproducibility & Applicability \\
\hline $\begin{array}{l}\text { Method is highly } \\
\text { specific. }\end{array}$ & $\begin{array}{l}30 \mathrm{ppm} \text { flame } \\
(30 \mu \mathrm{g} / \mathrm{mL})\end{array}$ & $\begin{array}{l}\text { Wet ashing is required. } \\
\text { Precision is dependent } \\
\text { upon the performance of } \\
\text { the wet chemistry } \\
\text { technique, not the actual } \\
\text { analytical method. }\end{array}$ & Universal
\end{tabular}

\section{Overall Evaluation}

Atomic absorption spectrometry with flame detector is a very good method to use for the detection of DU. The flame detector is as accurate as the graphite furnace apparatus, but is not as highly sensitive.

Atomic absorption spectrometry with a graphite furnace is an excellent method for the detection of DU. The operation can be fully automated; it is extremely sensitive; DU spectra are highly specific; an operator can easily be trained to maintain the instrument; the analysis is not extremely labor intensive; and there are few interferences.

Table A-11. Evaluation of alpha spectrometry as a method for the quantitative analysis of depleted uranium (Sill, 1977).

\begin{tabular}{|c|c|c|c|}
\hline Specificity & Sensitivity & Reproducibility & Applicability \\
\hline $\begin{array}{l}\text { Method is highly } \\
\text { specific. Can be used } \\
\text { for the isolopic } \\
\text { determination of } \\
238 \mathrm{U}, 235 \mathrm{U} \text {, and }{ }^{234} \mathrm{U} \text {. }\end{array}$ & $100 \mu \mathrm{g} / \mathrm{mL}$ & $\begin{array}{l}\text { Precision is dependent } \\
\text { upon the performance of } \\
\text { the wet chemistry } \\
\text { technique, not the actual } \\
\text { analytical method. }\end{array}$ & Universal \\
\hline
\end{tabular}

\section{Overall Evaluation}

Method is extremely expensive and highly skilled professionals are needed to set up apparatus. Recommended only if isotopic ratios are needed, othenwise, a less expensive method is recommended. 
Table A-12. Evaluation of delayed neutron emission as a method for the quantitative analysis of depleted uranium (Amiel, 1962).

\begin{tabular}{|c|c|c|c|}
\hline Specificity & Sensitivity & Reproducibility & Applicability \\
\hline $\begin{array}{l}\text { Method is highly } \\
\text { specit:: Good method } \\
\text { for measuring the } \\
\text { isotopic composition } \\
\text { of } U \text {. }\end{array}$ & $1 \mu \mathrm{g} / \mathrm{mL}$ & $\begin{array}{l}\text { Rapid, automated analyses } \\
\text { can be pertormed at the rate } \\
\text { of approximately } 100 \text { per } 8-h \\
\text { day. Needs no professional } \\
\text { staff. Precision is dependent } \\
\text { upon the performance of } \\
\text { the wet chemistry } \\
\text { technique, not the actual }\end{array}$ & Universal \\
\hline
\end{tabular}

method.

\section{Overall Evaluation}

Beryllium can also be a source of neutrons and, therefore, a possible interference compound for the analysis of DU. Thus, this method would not be desirable for a multielement analysis of both Be and DU.

Table A-13. Evaluation of emission spectroscopy with inductively coupled plasma excitation source (ICP or ICAP) as a method for the quantitative analysis of depleted uranium (Mallessa, 1978).

\begin{tabular}{|c|c|c|c|}
\hline Specificity & Sensitivity & Reproducibility & Applicability \\
\hline $\begin{array}{l}\text { Method can give } \\
\text { simultaneous information } \\
\text { on several elements at one } \\
\text { time. However, the plasma } \\
\text { zone is highly specitic for } \\
\text { each element. }\end{array}$ & $0.03 \mu \mathrm{g} / \mathrm{mL}$ & $\begin{array}{l}\text { Reproducibility is excellent, the } \\
\text { method can be fully automated. } \\
\text { Although solid samples can be } \\
\text { measured directly, standardization } \\
\text { is difficult for solids; therefore, samples } \\
\text { should be in solution. Precision is } \\
\text { dependent upon the performance of } \\
\text { the wel chemistry technique, not the } \\
\text { actual analylical method. }\end{array}$ & Universal \\
\hline
\end{tabular}

\section{Overall Evaluation}

The ICP method requires the addition of internal standards, which would be more labor intensive than other methods. This method can be readily automated; it is highly sensitive; it can analyze more than one element at a time, and is, therefore, excellent for multiple analyses. 
Table A-14. Evaluation of emission spectroscopy with inductively coupled plasma excitation source and mass spectrometry (ICP/MS) as a method for the quantitative analysis of depleted uranium (Russ, 1988).

Specificity
Method can give
simultaneous information
on several elements at one
time. However, the plasma
zone is highly specitic tor
each element. Mass
spectrometry can also
fingeprint each element.

Sensitivity

Reproducibility

Applicability

$11010 \mathrm{ppb}$

(0.001 to $0.01 \mu \mathrm{g} / \mathrm{mL}$ )
Reproducibility is about 1 to $2 \%$.

Precision is dependent upon

the performance of the wet chemistry technique, not the actual analytical method.

\section{Overall Evaluation}

The ICP method requires the addition of internal standards, which would be more labor intensive than other methods. There are also limitations in the upper concentration that can be measured, approximately $1 \mathrm{ppm}$ is the limit. This method can be readily automated; it is highly sensitive; it can analyze more than one element at a time, and is, therefore, excellent for multiple analyses.

Table A-15. Evaluation of mass spectrometry (MS) with fission track analysis as a method for the quantitative analysis of depleted uranium (Myers and White, 1971).

\begin{tabular}{|c|c|c|c|}
\hline Specificity & Sensitivity & Reproducibility & Applicability \\
\hline $\begin{array}{l}\text { Methad is highly specilic. } \\
\text { MS provides isolopic } \\
\text { ratios of U present. } \\
\text { time. However, the plasma }\end{array}$ & $\begin{array}{l}0.03 \mathrm{ng} / \mathrm{m}^{3} \\
\text { (lowest reported) } \\
\text { approximately } \\
3 \times 10^{-11} \mu \mathrm{g} / \mathrm{mL}\end{array}$ & $\begin{array}{l}\text { Precision is dependent upon } \\
\text { the performance of the wet } \\
\text { chemistry technique, not the } \\
\text { actual analytical method. }\end{array}$ & Universal \\
\hline
\end{tabular}

each element. Mass

spectromelry can also

tingerprint each element.

\section{Overall Evaluation}

MS with fission track analysis is an excellent method for the detection of DU in airborne particulate matter; however, the instrumentation is expensive and it requires highly skilled aperators. 
Table A-16. Evaluation of neutron activation analysis (NAA) as a method for the quantitative analysis of depleted uranium (Pankartz, 1988).

$\begin{array}{llll}\text { Specificity } & \text { Senșitivity } & \text { Reproducibility } & \text { Applicability } \\ \begin{array}{l}\text { Method is highly specific. } \\ \text { It can provide isotopic }\end{array} & 2 \times 10^{-10} \mu \mathrm{g} / \mathrm{mL} & \begin{array}{l}\text { Accuracy } \pm 4 \% . \text { Precision } \\ \text { is dependent upon the } \\ \text { ratios of } U .\end{array} & \begin{array}{l}\text { performance of the wet } \\ \text { chemistry technique, not the } \\ \text { actual analytical method. }\end{array}\end{array}$

\section{Overall Evaluation}

NAA is an excellent method for the highly sensitive analysis of airborne DU particles. It is, however, an extremely expensive, commercially available technique, and samples can take up to six weeks before results are produced due to the radioactive nature of the analysis.

Table A-17. Evaluation of polarography as a method for the quantitative analysis of depleted uranium (Zittel and Dunlap, 1962).

\begin{tabular}{|c|c|c|c|}
\hline Specificity & Sensitivity & Reproducibility & Applicability \\
\hline $\begin{array}{l}\text { Method alone is } \\
\text { nonspecific. It must be } \\
\text { used in conjunction with } \\
\text { other methods to eliminate } \\
\text { interference compounds. }\end{array}$ & 100 to $400 \mu \mathrm{g} / \mathrm{mL}$ & $\begin{array}{l}\text { Accuracy } \pm 3 \% \text {. Precision } \\
\text { is dependent upon the } \\
\text { performance of the wet } \\
\text { chemistry technique, not the } \\
\text { actual analytical method. }\end{array}$ & Universal \\
\hline
\end{tabular}

with DU.

\section{Overall Evaluation}

There are several compounds that may interfere with $D U$ and must be eliminated; this can be a very labor-intensive procedure. 
Table A-18. Evaluation of thermal ionlzation mass spectrometry as a method for the quantitative analysis of depleted uranium (Russ, 1988).

\begin{tabular}{|c|c|c|c|}
\hline Specificity & Sensitivity & Reproducibility & Applicability \\
\hline $\begin{array}{l}\text { Method is highly specific. } \\
\text { it can provide the minor } \\
\text { isotopes of } U \text {. }\end{array}$ & $\begin{array}{l}1 \text { to } 10 \mathrm{ppb} \\
(0.001100 .01 \mu \mathrm{g} / \mathrm{mL})\end{array}$ & $\begin{array}{l}\text { Reproducibility about } 0.1 \% \text {. } \\
\text { Precision is dependent upon the } \\
\text { pertormance of the wet } \\
\text { chemistry lechnique, not the } \\
\text { actual analytical method. }\end{array}$ & Universal \\
\hline
\end{tabular}

\section{Overall Evaluation}

Thermal ionization MS is an excellent method for the detection of DU. The operation can be fully automated; it is extremely sensitive; DU spectra are highly specific; and there are few interferences. However, sample preparation can be quite labor intensive.

Table A-19. Evaluation of $\mathrm{X}$-ray fluorescence as a method for the quantitative analysis $0_{i}$ beryllium (Dulka and Risby, 1978).

$\begin{array}{llll}\text { Specificity } & \text { Sensitivity } & \text { Reproducibility } & \text { Auplicability } \\ \begin{array}{l}\text { Method atone is } \\ \text { nonspecific. It must be }\end{array} & 0.002 \mu \mathrm{g} / \mathrm{mL} & \begin{array}{l}\text { Precision is dependent } \\ \text { upon the performance of } \\ \text { the wet chemistry technique } \\ \text { used in conjunction with }\end{array} & \text { Universal } \\ \text { other methods to } & & \text { net the actual analytical } \\ \text { eliminate interlerence } & & & \\ \text { compounds. Fe(ll) } & & & \\ \text { strongly interferes } & & & \\ \text { with DU. } & & \end{array}$

\section{Overall Evaluation}

The analysis of DU samples using $x$-ray fluorescence is more sensitive than that of $x$-ray fluorescence detection of $\mathrm{Be}$; it can, however, be labor intensive, due to the necessary elimination of interference compounds to the DU spectra. A monochromatic source would definitely be needed to reduce the interferences and automate the system. 


\section{Appendix B. Criteria for the Selection of Commercial Analysis of $\mathrm{Be}$ and DU}

As part of our evaluation of analytical methods for the detection of Be and DU. we conducted a survey of about 50 companies and institutions and used the following criteria to evaluate them:

1. AlHA certification.

2. Turnaround time for 150 samples.

3. Cost per sample.

4. Method of analysis.

5. Sensitivity.

6. Ability to measure with precision $0.05 \mathrm{mg}$ Be and $0.25 \mathrm{mg} \mathrm{OU}$.

O1 the companies and other institutions that were surveyed, we recommend the following in ranking order with regard to these criteria:

1. Aerovironment Inc., Monrovia, CA.

2. Nuclear Consulting Service, Columbus, $\mathrm{OH}$.

3. Global Geochemistry, Pasadena, CA.

4. Fireman's Fund, Petaluma, CA.

5. Hazen Laboratories, Golden, $C O$.

6. Environmental Monitoring and Services Inc., Newberry Park, CA.

7. IT Comporation, Richmond, CA.

8. Radiation Detection Col, Sunnyvale, CA.

9. TMA-Norcal, Richmond, CA.

10. Kennedy/Jenks Engineers, San Francisco, CA.

The following pages provide more information about these companies and about the other companies and institutions surveyed. 


\section{Recommended Companies}

Table B-1. Aerovironment Inc., Monrovia, CA, a recommended company (contact Dave Pankartz at (818) 357-9983).

Criteria

AlHA certification

Measurement precision

Turnaround time for 150 samples

Cost per sample

Be analysis method

Preliminary preparation

Specificity

Sensilivity

Reproducibility

Applicability

Method of analysis for DU

Prelimınary preparation

Specificity

Sensitivity

Reproducibility

Other
Comment

Analysis not done by this company, must subconiract, AlHA certification might be a problem

More precise than $0.05 \mathrm{mg} \mathrm{Be}$ and $0.25 \mathrm{mg} \mathrm{DU}$

10 to 20 days

$\$ 20$ to 30 for total analysis of sample, $\$ 5,000$ for 150 samples excluding NAA AA with graphite fumace/ICP

Acid digestion

Highly specific

$0.04 \mu \mathrm{g}$

Precision based on pertormance of wet chemistry, should send spikes and blanks to test method

Universal

XFF or ICP or NAA (\$300 to 400/sample, cannot do NAA vith Be, results can take up to six weeks)

Acid digestion

Highly specific

$0.09 \mu 9$

Precision based on pertormance of wet chemistry, should send spikes and blanks to test method

Universal

Also able to do Hi-Vol air sampling. Set up equipment and rental approximately $1.500 /$ year 
Table B-2. Nuclear Consulting Service, Columbus, $\mathrm{OH}$, a recommended company (contact Dr. Steve Monlar (614) 846-5710).

\begin{tabular}{|c|c|}
\hline Criteria & Comment \\
\hline AlHA certification & No, company does have a radioisolope license \\
\hline Measurement precision & More precise than $0.05 \mathrm{mg} \mathrm{Be}$ and $0.25 \mathrm{mg} \mathrm{DU}$ \\
\hline Turnaround time for & \\
\hline 150 samples & 30 days \\
\hline Cost per sample & $\$ 25 /$ sample/element, $\$ 50$ for total analysis of sample \\
\hline Be analysis method & AA with graphite furnace \\
\hline Preliminary preparation & Acid digestion \\
\hline Specificity & Highly specific \\
\hline Sensitivity & $0.04 \mu \mathrm{g}$ \\
\hline Reproducibility & $\begin{array}{l}\text { Precision based on nerformance of wet chemistry, should send spikes and } \\
\text { blanks to tesi . . uthod }\end{array}$ \\
\hline Applicability & Universal \\
\hline Method of analysis fc: DU & AA with graphite furnace \\
\hline Preliminary preparation & Acid digestion \\
\hline Specificity & Highty specific \\
\hline Sensitivity & $0.09 \mu \mathrm{g}$ \\
\hline Reproducibility & $\begin{array}{l}\text { Precision based on performance of wet chemistry, should send spikes and } \\
\text { blanks to test method }\end{array}$ \\
\hline Applicability & Universal \\
\hline Other & Also able to do Hi-Vol air sampling approximately $\$ 275 /$ day or $\$ 50 / \mathrm{h}$. \\
\hline
\end{tabular}

\section{Table B-3. Global Geochemistry, Pasadena, CA, a recommended company (contact Dr. Ian Kaplan (818) 992-4103).}

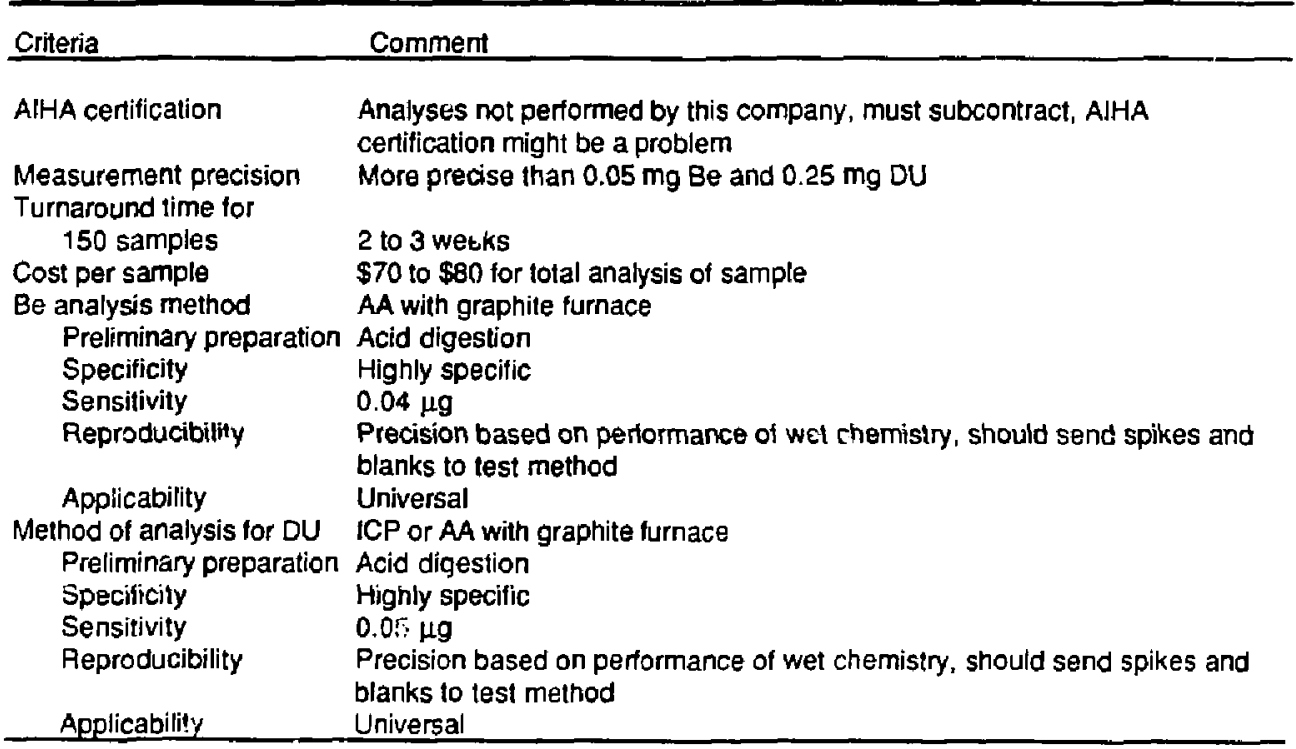


Table B-4. Fireman's Fund, Petaluma, CA, a recommended company (contact Jerry Tuma (707) 778-4173).

\begin{tabular}{|c|c|}
\hline Criteria & Comment \\
\hline AIHA certifiçation & Yes \\
\hline Measurement precision & More precise than $0.05 \mathrm{mg} \mathrm{Be}$ and $0.25 \mathrm{mg} \mathrm{DU}$ \\
\hline $\begin{array}{l}\text { Iumaround time for } \\
150 \text { samples }\end{array}$ & 2 to 3 weeks \\
\hline Cost per sample & $\$ 70.40 /$ sample total analysis \\
\hline Be analysis method & AA with graphite furnace \\
\hline Preliminary preparation & Acid digestion \\
\hline Specificity & Highly specific \\
\hline Sensititity & $0.04 \mu g$ \\
\hline Reproducibility & $\begin{array}{l}\text { Precision based on performance of wet chemistry, should send spikes and } \\
\text { blanks to test method }\end{array}$ \\
\hline Applicability & Universal \\
\hline Method of analysis for DU & $\mathrm{ICP}$ \\
\hline Preliminary preparation & Acid digestion \\
\hline Specificity & Highly specific \\
\hline Sensitivity & $0.05 \mu \mathrm{g}$ \\
\hline Reproducibility & $\begin{array}{l}\text { Precision based on pertormance of wet chemistry, should send spikes and } \\
\text { blanks to test method }\end{array}$ \\
\hline Applicability & Universal \\
\hline
\end{tabular}

Table B-5. Hazen Laboratories, Golden, CO, a recommended company (contact Bob Rostab (303) 279-4501).

\begin{tabular}{|c|c|}
\hline Criteria & Comment \\
\hline AIHA certification & Yes \\
\hline $\begin{array}{l}\text { Measurement precision } \\
\text { Turnaround time for }\end{array}$ & More precise than $0.05 \mathrm{mg} \mathrm{Be}$ and $0.25 \mathrm{mg} \mathrm{DU}$ \\
\hline 150 samples & 2 weeks \\
\hline Cost per sample & $\$ 25.52 /$ sample total analysis \\
\hline Be analysis method & ICP \\
\hline $\begin{array}{l}\text { Preliminary preparation } \\
\text { Specificity }\end{array}$ & $\begin{array}{l}\text { Acid digestion } \\
\text { Highly specific }\end{array}$ \\
\hline Sensitivity & $0.2 \mu \mathrm{g}$ \\
\hline Reproducibility & $\begin{array}{l}\text { Precision based on performance of wel chemistry, should send spikes and } \\
\text { blanks to test method }\end{array}$ \\
\hline Applicability & Universal \\
\hline Method of analysis for DU & Fluorimetric \\
\hline Preliminary preparation & Acid digestion \\
\hline $\begin{array}{l}\text { Specificity } \\
\text { Sensitivity }\end{array}$ & Some interference compounds that need chemical separation \\
\hline $\begin{array}{l}\text { Sensitivity } \\
\text { Reproducibility }\end{array}$ & $\begin{array}{l}.03 \mathrm{\mu g} \\
\text { Precision based on performance of wet chemistry, should send spikes and } \\
\text { blanks to test method }\end{array}$ \\
\hline Applicability & Universal \\
\hline
\end{tabular}


Table B-6. Environmental Monitor $g$ and Services, Inc., Newberry Park, CA, a recommended company (contact Joe Matta (805) 388-5700).

\begin{tabular}{|c|c|}
\hline Criteria & Comment \\
\hline AlHA certification & Yes \\
\hline $\begin{array}{l}\text { Measurement precision } \\
\text { Turnaround time for }\end{array}$ & More precise than $0.05 \mathrm{mg} \mathrm{Be}$ and $0.25 \mathrm{mg} \mathrm{DU}$ \\
\hline 150 samples & 2 weeks \\
\hline Cost per sample & $\$ 41.00 /$ sample total analysis \\
\hline Be analysis method & $\mathrm{ICP}$ \\
\hline Preliminary preparation & Acid digestion \\
\hline Specificity & Highly specific \\
\hline Sensitivity & $0.2 \mu \mathrm{g}$ \\
\hline Reproducibility & $\begin{array}{l}\text { Precision based on performance of wet chemistry, should send spikes and } \\
\text { blanks to test method }\end{array}$ \\
\hline Applicability & Universal \\
\hline Method of analysis for DU & ICP \\
\hline Preliminary preparation & Acid digestion \\
\hline Speciticity & Highly specific \\
\hline Sensitivity & $50 \mu \mathrm{g} / \mathrm{L}$ or $50 \mathrm{ppb}(0.05 \mu \mathrm{g} / \mathrm{mL})$ \\
\hline Reproducibility & $\begin{array}{l}\text { Precision based on perlormance of wet chemistry, should send spikes and } \\
\text { blanks to test method }\end{array}$ \\
\hline Applicability & Universal \\
\hline
\end{tabular}

\section{Table B-7. IT Corporation, Cerritos, CA, a recommended company (contact Karen Jozeiak (213) 921-9831).}

\begin{tabular}{|c|c|}
\hline Criteria & Comment \\
\hline AlHA certification & Yes \\
\hline $\begin{array}{l}\text { Measurement precision } \\
\text { Tumaround time for }\end{array}$ & More precise than $0.05 \mathrm{mg} \mathrm{Be}$ and $0.25 \mathrm{mg}$ DU \\
\hline 150 samples & 2 weeks \\
\hline Cost per sample & $\$ 46.00 /$ sample total analysis \\
\hline Be analysis method & $\mathrm{ICP}$ \\
\hline Preliminary preparation & Acid digestion \\
\hline Specificity & Highly specific \\
\hline Sensitivity & $0.03 \mu \mathrm{g} / \mathrm{L}$ or $0.03 \mathrm{ppb}(0.03 \mu \mathrm{g} / \mathrm{mL})$ \\
\hline Reproducibility & $\begin{array}{l}\text { Precision based on performance of wet chemistry, should send spikes and } \\
\text { blanks to test method. (Wet chemistry method may be less precise than } \\
\text { purely instrumental analysis of sample.) }\end{array}$ \\
\hline Applicability & Universal \\
\hline Method of analysis for DU & ICP \\
\hline Preliminsry preparation & Acid digestion \\
\hline Specificity & Highly specific \\
\hline Sensitivity & $2 \mathrm{mg} / \mathrm{L}$ or $2 \mathrm{ppb}(2 \mathrm{mg} / \mathrm{mL})$ \\
\hline Reproducibility & $\begin{array}{l}\text { Precision based on performance of wet chemistry, should send spikes and } \\
\text { blanks to test method. }\end{array}$ \\
\hline Applicability & Universal \\
\hline Qther & This lab also performs NIOSH proficiency sample tests quanerly \\
\hline
\end{tabular}


Table B-8. Radiation Detection Company, Sunnyvale, CA, a recommended company (contact lab supervisor (415) 735-8700).

\begin{tabular}{|c|c|}
\hline Criteria & Comment \\
\hline AlHA certification & Yes \\
\hline Measurement precision & More precise than $0.05 \mathrm{mg}$ Be and $0.25 \mathrm{mg} \mathrm{DU}$ \\
\hline Turnaround time tor & \\
\hline $\begin{array}{l}150 \text { samples } \\
\text { Cost }\end{array}$ & 2 to 3 weeks \\
\hline Cost per sample & $\$ 29$ to $\$ 39$ tolal analysis \\
\hline Be analysis method & Fluorimetric \\
\hline Preliminary preparation & Acid digestion \\
\hline Specificity & Some interterence compounds that require chemical separation \\
\hline Sensitivity & $0.05 \mu \mathrm{g}$ \\
\hline Reproducibility & $\begin{array}{l}\text { Precision based on pertormance of wet chemistry, should send spikes and } \\
\text { blanks to test method }\end{array}$ \\
\hline Applicability & Universai \\
\hline Method of analysis for DU & Fluorimetric \\
\hline Preliminary preparation & not stated \\
\hline $\begin{array}{l}\text { Specificity } \\
\text { Sensitivity }\end{array}$ & Some interference compounds that require chemical separation \\
\hline $\begin{array}{l}\text { Sensitivity } \\
\text { Reproducibility }\end{array}$ & $\begin{array}{l}0.25 \mu \mathrm{g} \\
\text { Precision based on pertormance of wet chemistry, should send spikes and } \\
\text { blanks to test method }\end{array}$ \\
\hline Applicability & Universal \\
\hline
\end{tabular}

Table B-9. TMA-Norcal, Richmond, CA, a recommended company (contact Angela Davi (415) 235-2633).

\begin{tabular}{|c|c|}
\hline AlHA certification & Yes \\
\hline $\begin{array}{l}\text { Measurement precision } \\
\text { Tumaround time for }\end{array}$ & More precise than $0.05 \mathrm{mg} \mathrm{Be}$ and $0.25 \mathrm{mg} \mathrm{DU}$ \\
\hline $\begin{array}{l}150 \text { samples } \\
\text { Cost per sample }\end{array}$ & $\begin{array}{l}2 \text { to } 3 \text { months } \\
\$ 153.00 / \text { sample for air particles and } \$ 186.00 / \text { sample for soil (total analysis } \\
\text { including preliminary pieparation) }\end{array}$ \\
\hline $\begin{array}{l}\text { Be analysis method } \\
\text { Preliminary preparation } \\
\text { Speciticity } \\
\text { Sensitivity } \\
\text { Reproducibility }\end{array}$ & $\begin{array}{l}\text { Gel } \\
\text { Acid digestion } \\
\text { Highly specitic } \\
0.2 \mathrm{pCi} / \mathrm{m}^{3} \text { air particles and } 1 \mathrm{pCi} / \mathrm{g} \text { soil } \\
\text { Precision based on pertormance of wet chemistry, should send spikes and } \\
\text { blanks to test method }\end{array}$ \\
\hline Applicability & Universal \\
\hline Method of analysis for DU & Fluorimetric \\
\hline $\begin{array}{l}\text { Preliminary preparation } \\
\text { Specificity }\end{array}$ & $\begin{array}{l}\text { Acid digestion } \\
\text { Some interterence compounds that require chemical separation }\end{array}$ \\
\hline $\begin{array}{l}\text { Sensitivity } \\
\text { Reproducibility }\end{array}$ & $\begin{array}{l}0.5 \mathrm{pCi} / \mathrm{g} \\
\text { Precision based on performance of wet chemistry, should send spikes and } \\
\text { blanks to test method }\end{array}$ \\
\hline Applicability & Universal \\
\hline
\end{tabular}


Table B-10. Kennedy/Jenks Engineers, San Francisco, CA, a recommended company (contact Leverett Smith (415) 362-6065).

\begin{tabular}{|c|c|}
\hline Criteria & Comment \\
\hline AlHA certification & No, but hazardous waste certified \\
\hline Measurement precision & More precise than $0.05 \mathrm{mg}$ Be and $0.25 \mathrm{mg} \mathrm{DU}$ \\
\hline $\begin{array}{l}\text { Turnaround time for } \\
150 \text { samples }\end{array}$ & 2 to 3 weeks \\
\hline Cast per sample & $\$ 50.00 /$ sample total analysis \\
\hline Be analysis method & $\mathrm{ICP}$ \\
\hline Preliminary preparation & Acid digestion \\
\hline Specificity & Highly specitic \\
\hline Sensitivity & $0.05 \mathrm{mg} / \mathrm{kg}$ or $0.05 \mathrm{ppb}(0.05 \mu \mathrm{g} / \mathrm{mL})$ \\
\hline Reproducibility & $\begin{array}{l}\text { Precision based on pertormance of wet chemistry, should send spikes and } \\
\text { blanks to test method. This lab also performs NIOSH proficiency sample tests } \\
\text { quarterly. }\end{array}$ \\
\hline Applicability & Universal \\
\hline Method of analysis for DU & ICP \\
\hline Preliminary preparation & Acid digestion \\
\hline Specificity & Highly specific \\
\hline Sensitivity & Not determined \\
\hline Reproducibility & $\begin{array}{l}\text { Precision based on pertormance of wet chemistry, should send spikes and } \\
\text { blanks to test method. This lab also performs NIOSH proticiency sample tests } \\
\text { quarterly. }\end{array}$ \\
\hline Applicability & Universal \\
\hline
\end{tabular}




\section{Other Companies and Institutions}

Tabie B-11. Air Research Board, Riverside, CA, (contact Dr. Anga Bytnerowicz (714) 787-4716).

Criteria Comment

Comment

Does not do the work directly, must subcontract

Table B-12. Acurex Corporation, Mountain View, CA, (contact Claire Furguson (415) 964-3200).

Criteria

Comment

AlHA certification

Measurement precision

Turnaround time for

150 samples

Cost per sample

Be analysis method

Preliminary prepar

Specificity

Sensitivity

Reproducibility
Comment

Can only analyze Be

Yes

More precise than $0.05 \mathrm{mg} \mathrm{Be}$

2 to 3 weeks

$\$ 15 /$ sample

ICP or AA

No

Highly specific

0.01 ppm

Precision based on performance of wet chemistry, should send spikes and blanks to test method 
Table B-13. Battelle, Richland, WA (contact Monty Smith or Ron Brodzinski (509) 375-2121).

Criteria

Comment

AlHA certification

Measurement precision

Turnaround time for 150 samples

Cost per sample

Be analysis method

Preliminary preparation Acid digestion

Speciticity

Sensitivity

Reproducibility

Applicability

Method of analysis for DU

Preliminary preparation

Speciticity

Sensitivity

Peproducibility

Applicability

No

2 to 3 weeks

ICP

Highly specific

$0.01 \mathrm{ppm}$

Universal

Acid digestion

Highly specific

$1 \mathrm{ppb}$ or $1 \mathrm{ppt}$

Universal
Comment

Analyses done on extremely sensitive instruments, however, for routine analyses use a commercial laboratory recommended to meet the AlHA centification, rapid tumaround, and cost criteria

More precise than $0.05 \mathrm{mg} \mathrm{Be}$ and $0.25 \mathrm{mg} \mathrm{DU}$

$\$ 5000$ for 150 samples

Precision based on performance of wet chemistry. should send spikes and blanks to test method

ICPMS. Garnma-ray spectrometry, Mass spectrometry, Laser Fluorimetry

Precision based on performance of wet chemistry, should send spikes and blanks to test method

Table B-14. Brown and Coldwell, Emeryville, CA, (contact Barbara Danielson (415) 428-2300).

Criteria

Comment

Comment

Does not do the work directly, must subcontract 
Table B-15. Cal Analytical Labs, Sacramento, CA (contact Keri Freeman (916) $372-1393)$.

\begin{tabular}{ll} 
Criteria & Comment \\
\hline Comment & Can only analyze Be \\
AlHA certification & No \\
Measurement precision & More precise than $0.05 \mathrm{mg} \mathrm{Be}$ \\
Turnaround time tor & 3 to 4 weeks \\
150 samples & $\$ 14 /$ sample total analysis \\
Cost per sample & ICP \\
Be analysis method & Acid digestion \\
Preliminary preparation & Highly specific \\
Specificity & D.01 ppm \\
Sensitivity & Precision based on performance of wet chemistry, should send spikes and \\
Reproducibility & blanks to test method \\
Applicability & Universal \\
\hline
\end{tabular}

Table B-16. Chem West, Sacramento, CA (contact Margi Namba (916) 923-0840).

\begin{tabular}{ll} 
Criteria & Comment \\
\hline Comment & Can only analyze Be soil samples \\
AlHA centification & Yes \\
Measurement precision & More precise than $0.05 \mathrm{mg} \mathrm{Be}$ \\
Turnaround time for & \\
150 samples & 2103 weeks \\
Cost per sample & $\$ 55 /$ sample \\
Be analysis method & ICP \\
\multicolumn{1}{c}{ Preliminary preparation } & Acid digestion \\
Specificity & Highly specific \\
Sensitivity & 0.01 ppm \\
Reproducibility & Precision based on pertormance of wet chemistry, should send spikes and \\
& blanks to test method \\
Applicability & Universal \\
\hline
\end{tabular}


Table B-17. Clayton Laboratories, Pleasanton, CA (contact Mary Beck (916) 923-0840).

\begin{tabular}{|c|c|}
\hline Criteria & Comment \\
\hline Comment & Can only analyze Be \\
\hline AlHA certification & Yes \\
\hline Measurement precision & More precise than $0.05 \mathrm{mg} \mathrm{Be}$ \\
\hline $\begin{array}{l}\text { Turnaround time for } \\
150 \text { samples }\end{array}$ & 2 to 3 weeks \\
\hline Cost per sample & $\begin{array}{l}\$ 18 / \text { metalsample for air, } \$ 24 / \text { metal sample + sample preparation } \$ 25 \text {. For } \\
150 \text { samples, there is a } 10 \% \text { reduction in price; therefore, approximately } \\
\$ 44.10 \text { for total analysis }\end{array}$ \\
\hline Be analysis method & ICP or AA \\
\hline $\begin{array}{l}\text { Preliminary preparation } \\
\text { Specificity }\end{array}$ & $\begin{array}{l}\text { Acid digestion } \\
\text { Hiably specific }\end{array}$ \\
\hline Sensitivity & $0.05 \mathrm{ppm}$ \\
\hline Reproducibility & $\begin{array}{l}\text { Precision based on performance of wel chemistry, should send spikes and } \\
\text { blanks to test methad }\end{array}$ \\
\hline Applicability & Universal \\
\hline
\end{tabular}

Table B-18. J.M. Cohen and Company, Mountain View, CA (contact Tim Borman (415) 349-9737).

Criteria Comment

Comment Does not do the work directly, must subcontract

Table B-19. Curtis and Tomkins, San Francisco,CA (contact Debbie Howerd (415) 861-1863).

$\begin{array}{ll}\text { Criteria } & \text { Comment } \\ \text { Comment } & \text { Does not do the work directly, must subcontract }\end{array}$

Table B-20. Dames and Moore, Santa Barbara, CA (contact Bruce Whales (805) 685-4415).

Criteria Comment

Comment Does not do the work directly, must subcontract 
Table B-21. Desert Research Institute, Reno, NV (contact John Watson (702) $972-1676)$.

\begin{tabular}{|c|c|}
\hline Criteria & Comment \\
\hline Comment & $\begin{array}{l}\text { Analyses done on extremely sensitive instruments, however, for foutine } \\
\text { analyses, use a commercial laboratory recommended to meet the AIHA } \\
\text { certification, rapid tumaround, and cost criteria }\end{array}$ \\
\hline AlHA certification & No \\
\hline $\begin{array}{l}\text { Measurement precision } \\
\text { Turnaround time for }\end{array}$ & More precise than $0.05 \mathrm{mg} \mathrm{Be}$ and $0.25 \mathrm{mg} \mathrm{DU}$ \\
\hline 150 samples & 2 to 3 weeks, a couple of months before free to start \\
\hline Cost per sample & Not determined \\
\hline Be analysis method & AA \\
\hline Preliminary preparation & Acid digestion \\
\hline Specilicity & Highly specific \\
\hline Sensitivity & $50 \mathrm{ng} / \mathrm{mL}$ \\
\hline Reproducibility & $\begin{array}{l}\text { Precision based on periormance of wet chemistry, should send spikes and } \\
\text { blanks to test method }\end{array}$ \\
\hline Applicability & Universal \\
\hline Method of analysis for DU & X-ray fluorescence \\
\hline Freliminary preparation & Acid digestion \\
\hline Specilicity & Highly specific \\
\hline Sensitivity & $50 \mathrm{ng} / \mathrm{cm}^{2}$ deposit. (50 × $10^{-3} \mu \mathrm{g} / \mathrm{m}^{3}$ if Hi-Vol 8' $\times 10^{\prime}$ filters used) \\
\hline Reproducibility & $\begin{array}{l}\text { Precision based on pertormance of wet chemistry, should send spikes and } \\
\text { blanks to test method }\end{array}$ \\
\hline Applicability & Universal \\
\hline
\end{tabular}

\section{Table B-22. Dionex, Sunnyvale, CA (contact Peter Kanesky (408) 737-0700).}

Criteria

Comment

\section{Comment}

Problems with IC in the detection of Be. Would like to develop a now Be method using $\mathrm{IC}$ and willing to give as much technical information as needed. Uranium oxide can easily be run on IC down to $10 \mathrm{ppb}$ with techrique they have developed, which uses HPIC CS2 column and $50 \mathrm{mM} \mathrm{NH}_{4} \mathrm{SO}_{4}, 50 \mathrm{mM}$ $\mathrm{HNO}_{3}$ eluent as well as PAR suppressant. For more precise information on IC, call Peter Kanesky.

Table B-23. Ecology and Environment Inc., San Francisco, CA (contact Mike Williams (415) $362 \cdot 1010$ ). 
Table B-24. Ecoserve, Pittsburg, CA (contact Ripley Hunter (415) 439-5766).

\begin{tabular}{|c|c|}
\hline Criteria & Comment \\
\hline Comment & $\begin{array}{l}\text { Can only analyze Be. Able to do Hi-Vol air sampling for continuous sampling } \\
\text { with quarts/glass ol paper filters }\end{array}$ \\
\hline AlHA certification & No, but California Air Resources Board certified \\
\hline Measurement precision & More precise than $0.05 \mathrm{mg} \mathrm{Be}$ \\
\hline 150 samples & 10 days \\
\hline $\begin{array}{l}\text { Cost per sample } \\
\text { Be analysis method }\end{array}$ & $\begin{array}{l}\text { \$260/sample for total analysis } \\
\text { ICP }\end{array}$ \\
\hline Preliminary preparation & Acid digestion \\
\hline Specificity & Highly specific \\
\hline Sensitivity & $0.01 \mathrm{ppm}$ \\
\hline Reproducibility & $\begin{array}{l}\text { Precision based on performance of wet chemistry, should send spikes and } \\
\text { blanks to test method }\end{array}$ \\
\hline Applicability & Universal \\
\hline
\end{tabular}

Table 8-25. Engineering-Science Company, Arcadia, CA (contact Melony Baltezore (213) 445-7560).

\begin{tabular}{ll} 
Criteria & Comment \\
\hline Comment & Does not do the work directly, must subcontract
\end{tabular}

\section{Table B-26. Hager Laboratory, San Francisco, CA (contact Maggy (800) 282-1835).}

\begin{tabular}{|c|c|}
\hline Criteria & Comment \\
\hline Comment & Can only analyze Be. \\
\hline AlHA certification & Yes \\
\hline Measurement precision & More precise than $0.05 \mathrm{mg} \mathrm{Be}$ \\
\hline $\begin{array}{l}\text { Turnaround time for } \\
150 \text { samples }\end{array}$ & 2 to 3 weeks davs \\
\hline Cost per sample & not determined \\
\hline Be analysis method & MOA \\
\hline Preliminary preparation & Acid digestion \\
\hline Specificity & Highly specific \\
\hline Sensitivity & $0.01 \mathrm{ppm}$ \\
\hline Reproducibility & $\begin{array}{l}\text { Precision based on pertormance of wet chemistry, should send spikes and } \\
\text { blanks to test method }\end{array}$ \\
\hline Applicability & Universal \\
\hline
\end{tabular}


Table B-27. Joe Gorman, Ph.D. Associates, Claremont, CA (contact Dr. Gorman (714) 626-6675).

Criteria Comment

Comment Does not do the work directly, must subcontract

Table B-28. Lawrence Berkeley National Laboratory, Berkeley, CA (contact Jack Leveck (415) 486-4000).

Criteria

Comment

Comment

Analyses done on extremely sensitive instruments, however, for routine analyses, use a commercial laboratory recommended to meet the AlHA certification, rapid tumaround, and cost criteria

Table B-29. Metcalf and Eddy, Palo Alto, CA (contact Russell C. Holt (415) 969-9985).

\begin{tabular}{ll} 
Criteria & Comment \\
\hline Comment & Does not do the work directly, must subcontract
\end{tabular}

Table B-30. Oil Well Research, Long Beach, CA (contact Victor Hoff (213) 436-4254).

$\begin{array}{ll}\text { Criteria } & \text { Comment } \\ \text { Comment } & \text { Does not do the work directly, must subcontract }\end{array}$

Table B-31. Parsons Corporation, Pasadena, CA (contact Roy Gaunt (213) 440-2000).

Criteria Comment

Comment

Does not do the work directly, must subcontract 
Table B-32. R.I. Corporation, Ogden, UT (contact Richard Hentz (801) 393-8220).

Criteria Comment

Comment

Does not do the work directly, must subcontract

Table B-33. Rockwell International Environmental Monitoring and Services Center, Newberry Park, CA (contact G. Colovos (805) 498-6771).

Criteria Comment

Comment

Does nol do the work directly, must subcontract

Table B-34. Salt Lake Clty Research Center, Salt Lake City, UT (contact Dr. Al Whitehead, Jim Allen, or Bob Davidson (801) 524-5350).

Criteria Comment

Comment

This group has been extremely helpful. Analyses done on extremely sensitive instruments, however, for routine analyses, use a commercial laboratory recommended to meet the AlHA certification, rapid turnaround, and cost criteria

Table B-35. Sonoma Tech., Santa Rosa, CA (contact Don Blumenthal (805) 498-6771).

\section{Criteria}

Comment

\section{Comment}

Does not do the work directly, must subcontract; however, might be able to do the air sampling 
Table B-36. SRI, Menlo Park, CA (contact Ted Mill (415) 859-3605).

Criteria Comment

Comment

Analyses done on extremely sensitive instruments, however, for routine analyses, use a commercial laboralory recommended to meet the AIHA certification, rapid tumaround, and cost criteria

Table B-37. Trotter-Yoder and Associates, Lafayette, CA (contact (415) 284-2980).

Criteria Comment

Comment

Does not do the work directly, must subcontract

Table B-38. Truesdail Laboratorles, cos Angeles, CA (contact (213) 225-1654).

Criteria $\frac{\text { Comment }}{\text { Comment }}$ Does not do the work directly, must subcontract

Table B-39. Ultrachem Corporation, Walnut Creek, CA (contact E.H. Gallagher (415) 935-3115).

Criteria Comment

Comment

Does not do the work directly, must subcontract

Table B-40. UC Davis, Davis, CA (contact Tom Cahill (916) 752-1460).

Criteria Comment

Comment

Analyses done on extremely sensitive instruments, however, for routine analyses, use a commercial laboratory recommended to meet the AiHA certification, rapid turnaround, and cost criteria 
Table B-41. UCLA, Los Angeles, CA (contact Dr. Romney (213) 825-8776).

\begin{tabular}{|c|c|}
\hline Griteria & Comment \\
\hline Comment & $\begin{array}{l}\text { Can analyze Be only. Send all criteria necessary, with } 10 \text { to } 20 \text { samples in } \\
\text { poly v-caps, sealed tightly or glass scintillation vials approximately } 20 \mathrm{~mL} \text {. } \\
\text { Analyses done on extremely sensitive instruments, however, for routine } \\
\text { analyses, use a commercial laboratory recommended to meet the AlHA } \\
\text { cerification, rapid tumaround, and cost criteria }\end{array}$ \\
\hline AlHA certification & No \\
\hline $\begin{array}{l}\text { Measurement precision } \\
\text { Turnaround time tor }\end{array}$ & More precise than $0.05 \mathrm{mg} \mathrm{Be}$ \\
\hline 150 samples & Not determined \\
\hline $\begin{array}{l}\text { Cost per sample } \\
\text { Be analysis method }\end{array}$ & $\begin{array}{l}\text { \$5/sample } \\
\text { ICP/EM }\end{array}$ \\
\hline Preliminary preparation & Acid digestion \\
\hline Speciticity & Highly specific \\
\hline Sensitivity & Nol determined \\
\hline Reproducibility & $\begin{array}{l}\text { Precision based on performance of wet chemistry, should send spikes and } \\
\text { blanks to test method }\end{array}$ \\
\hline Applicability & Universal \\
\hline
\end{tabular}

Table B-42. UC Riverside, Riverside, CA (contact Gordon Bradford (714) 787-5109).

\begin{tabular}{|c|c|}
\hline Criteria & Comment \\
\hline Comment & $\begin{array}{l}\text { Analyses done on extremely sensitive instruments, however, for routine } \\
\text { analyses, use a commercial laboralory recommended to meet the AlHA } \\
\text { certification, rapid tumaround, and cost criteria }\end{array}$ \\
\hline AlHA certification & No \\
\hline $\begin{array}{l}\text { Measurement precision } \\
\text { Turnaround time for }\end{array}$ & More precise than $0.05 \mathrm{mg} \mathrm{Be}$ and $0.25 \mathrm{mg} \mathrm{DU}$ \\
\hline 150 samples & Less than 3 weeks \\
\hline Cost per sample & $\$ 25 /$ sample \\
\hline $\begin{array}{l}\text { Be analysis method } \\
\text { Preliminary preparation }\end{array}$ & $\begin{array}{l}\text { ICP } \\
\text { Acid digestion }\end{array}$ \\
\hline $\begin{array}{l}\text { Specilicity } \\
\text { Sensitivity }\end{array}$ & $\begin{array}{l}\text { Highly specific } \\
\text { ppb or less }\end{array}$ \\
\hline Reproducibility & $\begin{array}{l}\text { Precision based on pertormance of wet chemistry, should send spikes and } \\
\text { blanks to test method }\end{array}$ \\
\hline Applicability & Universal \\
\hline Method of analysis for DU & ICP \\
\hline Preliminary preparation & Acid digestion \\
\hline Specificity & Highly specific \\
\hline Sensitivity & ppm or less \\
\hline Reproducibility & $\begin{array}{l}\text { Precision based on performance of wet chemistry, should send spikes and } \\
\text { blanks to test method }\end{array}$ \\
\hline Applicability & Universal \\
\hline
\end{tabular}


Table B-43. US Department of Agriculture Forest Fire Lab, Riverside, CA (contact Dave Hamilton (714) 351-6523).

$\begin{array}{ll}\text { Criteria } & \text { Comment } \\ \text { Comment } & \begin{array}{l}\text { Arıalyses done on extremely sensitive instruments, however, for routine } \\ \text { analyses, use a commercial laboratory recommended to meet the AlHA } \\ \text { certification, rapid turnaround, and cost criteria }\end{array}\end{array}$

Table B-44. US Department of Agriculture Salinity Laboratory, Riverside, CA (contact Don Saurez (415) 752-1460).

Criteria

Comment

\section{Comment}

Can only perform analyses if ambient Be and DU are affecting environment. Analyses done on extremely sensitive instruments, however, for routine analyses, use a commercial laboratory recommended to meet the AlHA certification, rapid tumaround, and cost criteria

Table B-45. Woodward-Clyde Consultants, San Francisco, CA (contact Jim Sarter (415) 434-1955).

Criteria

Comment

\author{
Comment
}

Does not do the work directly, must subcontract 